\title{
Resettlement preferences from landslide prone areas in Cameroon: Willingness to move, reasons to stay
}

\author{
Highlights
}

Resettlement as a disaster risk reduction strategy entails a threat for livelihoods

Individual resettlement preferences show heterogeneity, linked to wealth

Poor households attach importance to their social network

There is a mismatch between group behavior and individual preferences

Trust, group behavior and historical events are therefore important for resettlement

\section{Key words}

Discrete choice experiment, relocation, resettlement, landslides, disaster risk reduction, Bamboutos caldera

\begin{abstract}
Information about resettlement preferences is an important prerequisite for the success of voluntary resettlement as a disaster risk reduction strategy. Yet, even in conditions where individual preferences for resettlement are met, resettlement programs may fail. In this study, we confront individual preferences for resettlement with obstacles to resettlement in order to identify conditions for success and failure of voluntary resettlement. Semi-structured interviews and focus groups discussions are combined with a structured household survey and a discrete choice experiment to elicit individual resettlement preferences among farmers living in the landslide-prone Bamboutos caldera, in Cameroon. A mixed logit model and a latent class model are used to assess resettlement preferences and to investigate differences in preferences between socioeconomic groups. We find that, in general, people are willing to resettle away from landslide prone areas to safer areas, but that preferences for resettlement conditions vary between socioeconomic groups. Wealthier households show a greater willingness to resettle, especially to locations with improved road infrastructure, while poorer respondents are less willing to resettle, especially when this can negatively affect their social network. Beyond individual preferences, resettlement strongly depends on group behavior, historical events and trust in institutions. The stumbling blocks in the Bamboutos caldera include border disputes at the resettlement location, the high cost of resettlement and administrative challenges. With this case study, we demonstrate the added value of complementing a discrete choice experiment with qualitative research, as it leads to an integrated view of the resettlement situation of the affected population.
\end{abstract}




\section{Introduction}

Climate change and increasing population pressure in high risk areas are increasing the prevalence of natural disasters around the world (Artur and Hilhorst, 2014; Dai et al., 2002). One example of a natural disaster that is affected by climate change is landslides (Gariano and Guzzetti, 2016; Huggel et al., 2013; Reder et al., 2016). Climate change is predicted to modify raining patterns so that more rain will fall in shorter bursts of time (Cifrodelli et al., 2015; Huggel et al., 2013; Reder et al., 2016), thereby increasing landslide frequency (Gariano et al., 2017; Komori et al., 2018; Rianna et al., 2014). Landslides can have devastating effects on local communities. In African agricultural communities they have been found to reduce agricultural productivity, damage infrastructure and cause casualties (Froude and Petley, 2018; Mertens et al., 2016; Mugagga et al., 2012; Van Eynde et al., 2017).

If one treats risk as the outcome of the risk equation (Risk = hazard $\mathrm{x}$ vulnerability $\mathrm{x}$ elements at risk), strategies to reduce disaster risk can be subdivided into three categories (Crozier and Glade, 2005): elimination of the hazard, measures to lower the vulnerability and avoidance of exposure (Artur and Hilhorst, 2014). While eliminating landslide hazard or vulnerability is not evident due to the widespread occurrence of unstable slopes and poverty, spatial planning and development of early-warning systems can reduce the elements at risk. However, spatial planning requires strict enforcement and monitoring, which is often ineffective in areas with high population density, land shortages and/or weak institutions (Claessens et al., 2007; Knapen et al., 2006).

Permanent resettlement is a strategy to reduce exposure (Anderson et al., 2011; Artur and Hilhorst, 2014; Churchill and Hutchinson, 1984; Claudianos, 2014; Correa et al., 2011; Vlaeminck et al., 2016). However, it comes with questions of feasibility and social acceptability. Research has shown that resettlement can lead to increased landlessness, loss of social networks, unemployment, homelessness, food insecurity and other adverse effects (Cernea, 1997). Careful planning can reduce the chance that these adverse effects occur, but resettlement will continue to entail risks for the considered population. Consequently, due to the problems and limitations, some authors consider resettlement a measure of last resort (Ferris, 2014; Kita, 2017).

In the past, resettlement strategies have failed because of inappropriate design, insufficient infrastructure, ownership issues, cultural inappropriateness and problems of affordability (Sridarran et al., 2018). It is therefore very important to involve the populations from the start and to know the preferences of the villagers. A successful resettlement strategy is one that is instigated by the resettlers themselves. Earlier research in developing countries revealed that the willingness to accept a resettlement program rises with the amount of compensation, previous negative experience of the population with natural disasters, the attractiveness of the resettlement destination, the level of participation of the affected population in the design of the resettlement program and the size of land offered to the households (Arnall et al., 2013; Artur and Hilhorst, 2014; Churchill and Hutchinson, 1984; Correa et al., 2011; et al., 2017; Vlaeminck et al., 2016). Willingness to resettle might be lower among poorer households, because the poor tend to be more risk-averse (Dercon, 2002). This is particularly true for downside risks (i.e. loss aversion), since the livelihoods of poor people are severely affected by negative income shocks, like those caused by resettlement (Kahneman and Tversky, 1979; Mertens et al., 2016; Mertens and Vranken, 2018). Key determinants of satisfaction after resettlement are the level of consultation and the number of choices offered, rather than the income levels reached after the resettlement (Claudianos, 2014; Fujikura and Nakayama, 2012). Therefore, it is important to know the preferences of farmers and take their desires and needs into account when designing and implementing resettlement programs.

Most studies concerning such preferences, however, examine resettlements that were initiated by an external agent or investigate hypothetical resettlement in conditions where no previous resettlement (attempt) has taken place (Vlaeminck et al., 2016). It is therefore hard to verify which combinations of conditions turn a resettlement attempt into a success.

This study compares successful, unsuccessful and non-attempted resettlements in one and the same region, all of which were locally initiated, with and without compensation offered by the government. We combine semi-structured interviews (SSI) and focus group discussions (FGD) with a structured household-survey that includes a discrete choice experiment (DCE) to identify which conditions are 
determinants for the success of (future) resettlement programs. The combination of different methods allows us to identify and explain the differences in attitudes towards resettlement across village communities, while at the same time understanding individual preferences for different types of hypothetical resettlement.

\section{Study area}

The Bamboutos caldera is situated in the Wabane Sub-Division of Lebialem in the Southwest region of Cameroon (Figure 1). The 13 by $8 \mathrm{~km}$ elliptically shaped crater is characterized by a high elevation gradient and dissected slopes. It reaches up to 2740 meters and is located more than $30 \mathrm{~km}$ from main urban centers and approximately $20 \mathrm{~km}$ from the nearest paved road (Gountie et al., 2011; Ngoufo, 1992). The precipitation reaches between 2000 and $3000 \mathrm{~mm}$ annually, which mainly falls during the rainy season that lasts from March to October (Toh et al., 2018).

Wabane is inhabited by approximately 62,000 inhabitants who can be divided into three ethnic groups: Mundani, M'mouck and Fulani (Wabane Council, 2012). While no exact figures are available, the Bamboutos caldera is said to be the most populated caldera of the Cameroon Volcanic Line (CVL) (Wouatong et al., 2014; Zangmo et al., 2011). The population is estimated to reach approximately 19,000 people (Toh et al., 2018). Most of the people belong to the Mundani clan who can be found throughout the caldera. The M'mouck form a smaller group in the caldera who live predominantly in the southern part of the caldera. The Mundani and M'mouck are Christians and participate in farming activities. A third group is the Fulani or Fulbe. This ethnic group is Muslim, has a nomadic lifestyle and constitutes only a very small percentage of the population living in the caldera. Besides state administration and local leaders, a paramount chief is responsible for the traditional or cultural leadership in the region. Most of the population is concentrated at the montane savannah zone at the crescentshaped edge of the crater.

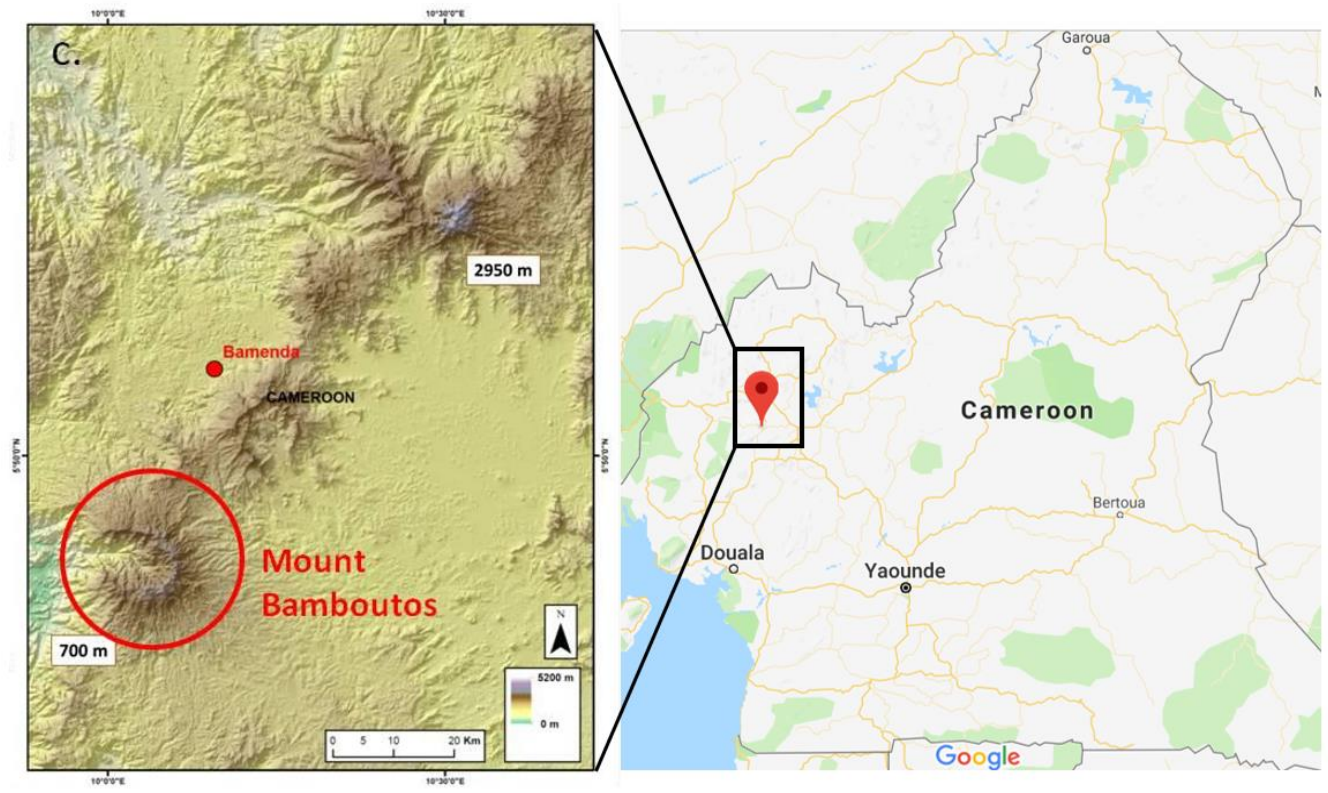

Figure 1: Location of Bamboutos caldera in Cameroon. Maps originate from (Kervyn et al., 2015) and google.com respectively.

The caldera is mainly composed of felsic rocks, which form fertile soils that are cultivated by smallholder farmers who produce high input-high value crops, such as potatoes, cabbages, leeks, carrots and maize for the nearby cities of Baffousam, Bamenda and Dschang (Toh et al., 2018; Zangmo et al., 2011). Increasing population pressure has led people to settle on the steeper slopes (Guedjeo et al., 2013; Lambi and Ndenecho, 2010), which are frequently affected by both small and large landslides in the raining season (Wouatong et al., 2014; Zangmo et al., 2011), leaving the population exposed. The authorities at both the local and the national level promote a risk zonation policy (Maes et al., 2018). 
However, poor enforcement and the lack of transparency have prevented this policy from leading to effective risk reduction (Maes et al., 2018). Some villages in the Bamboutos caldera have already resettled or have attempted to do so, while others do not consider it a relevant option for now. The differences in resettlement preferences between households and villages are related to historical processes in the region, which makes the Bamboutos caldera an excellent region for the study of resettlement as a coping strategy.

We sampled six villages distributed along the landslide-prone areas of the caldera, with different development and resettlement histories (Table 1). A map of the caldera and the villages is shown in Figure 2 . The road quality differs across villages, with Nkongle being the most accessible and Fomenji being the most isolated. The dominant agricultural system in the caldera is potato-based cash cropping. The exceptions are Fomenji and the parts of Magha situated at lower altitudes where food cropping based on cocoyam and banana cultivars is more prevalent. The population pressure (own observations and interviews, based on the availability of free parcels) is highest in Nkongle and lowest in Fomenji. The dominant language in the northern villages is Mundani, whereas it is M'mouck in the southern villages (Table 1). The six villages investigated have been affected by landslides, but some more severely than others (Table 1 ).

Table 1: Village-level characteristics based on observations during fieldwork (2017).

\begin{tabular}{|c|c|c|c|c|c|}
\hline Village & Fomenji & Magha & Atsualah & $\begin{array}{c}\text { Aghong \& } \\
\text { Marita }^{\mathrm{a}}\end{array}$ & Nkongle $^{b}$ \\
\hline $\begin{array}{l}\text { Connectivity by } \\
\text { road }\end{array}$ & $\begin{array}{c}\text { Isolated, } \\
\text { limited access } \\
\text { by motorcycle }\end{array}$ & $\begin{array}{l}\text { Access by motorcycle } \\
\text { year-round, terrain } \\
\text { vehicle in summer }\end{array}$ & $\begin{array}{l}\text { Access by } \\
\text { terrain vehicle }\end{array}$ & $\begin{array}{l}\text { Access by } \\
\text { terrain } \\
\text { vehicle }\end{array}$ & Access by car \\
\hline $\begin{array}{l}\text { Dominant } \\
\text { agricultural } \\
\text { system }\end{array}$ & Food cropping & Combination & $\begin{array}{l}\text { Cash } \\
\text { cropping }\end{array}$ & $\begin{array}{l}\text { Cash } \\
\text { cropping }\end{array}$ & $\begin{array}{l}\text { Cash } \\
\text { cropping }\end{array}$ \\
\hline $\begin{array}{l}\text { Population } \\
\text { pressure }\end{array}$ & Low & Medium & Medium & Medium & High \\
\hline $\begin{array}{l}\text { Dominant } \\
\text { language }\end{array}$ & Mundani & Mundani & Mundani & M'mouck & M'mouck \\
\hline $\begin{array}{l}\text { Affected by } \\
\text { landslides }\end{array}$ & $\begin{array}{c}\text { Houses } \\
\text { damaged at } \\
\text { multiple points } \\
\text { in time }\end{array}$ & 23 casualties in 2003 & $\begin{array}{l}\text { Major } \\
\text { damage to } \\
\text { houses in } \\
2003\end{array}$ & $\begin{array}{l}\text { Minor } \\
\text { damage to } \\
\text { crops }\end{array}$ & $\begin{array}{c}\text { Houses } \\
\text { damaged at } \\
\text { multiple } \\
\text { points in time }\end{array}$ \\
\hline Resettlement & $\begin{array}{l}\text { No } \\
\text { resettlement }\end{array}$ & $\begin{array}{l}\text { Unsuccessful } \\
\text { resettlement attempt in } \\
2003\end{array}$ & $\begin{array}{l}\text { Successful } \\
\text { resettlement } \\
\text { from } 2003 \\
\text { onwards }\end{array}$ & $\begin{array}{l}\text { Resettlement } \\
\text { in } 1988, \text { to } \\
\text { gain access } \\
\text { to road }\end{array}$ & $\begin{array}{l}\text { No } \\
\text { resettlement }\end{array}$ \\
\hline
\end{tabular}

a) Aghong and Marita are strictly speaking separate villages but were considered together, since they have a very similar background and considering them together reduces repetition and improves readability. b) The marketplace at Nkongle is the central point of what are, strictly speaking, several bordering villages. 


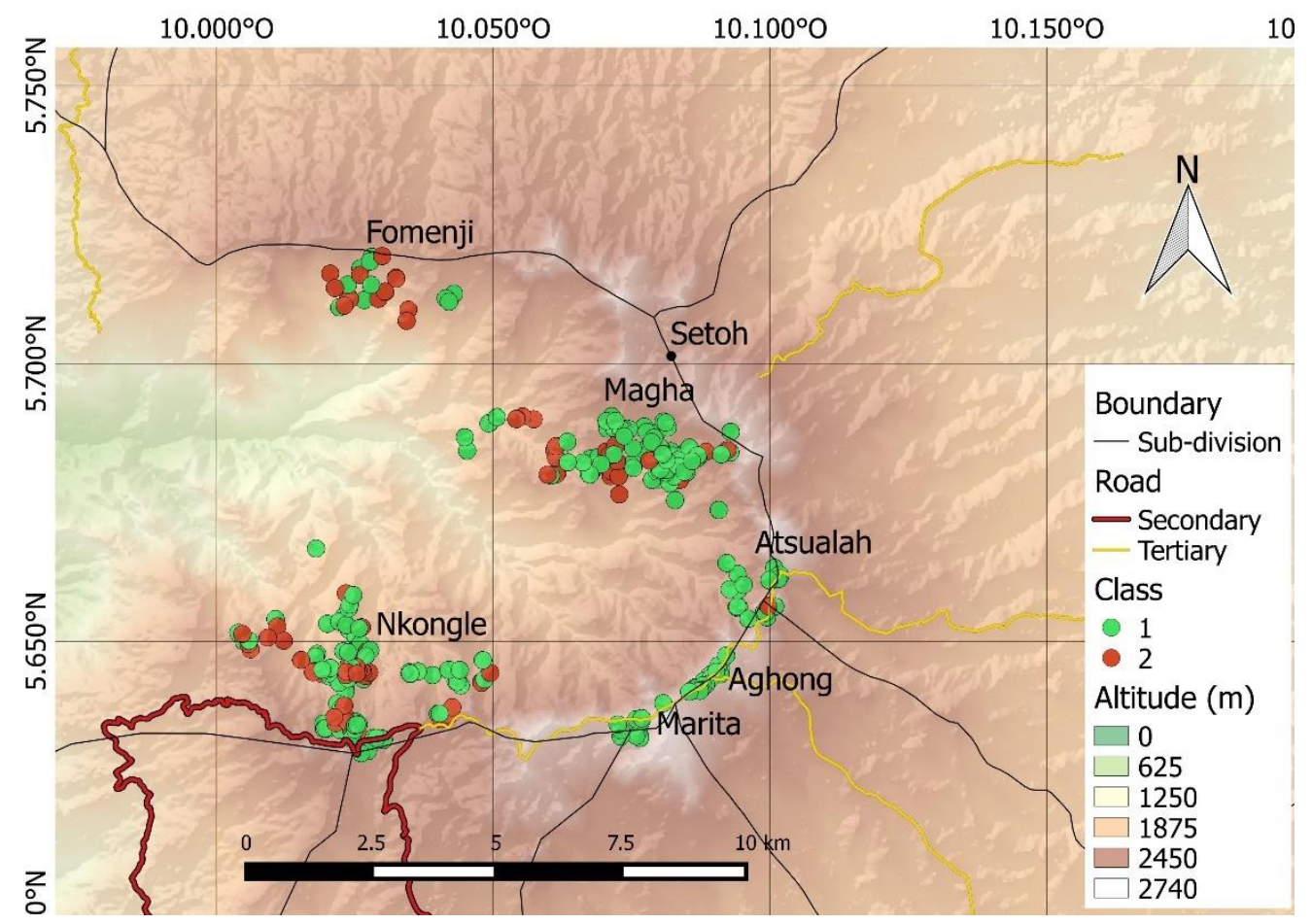

Figure 2: Map of the Bamboutos caldera. Each point represents the location of an interviewed household. The isolated village of Fomenji is visible in the northwest. Setoh is located at the boundary of the sub-division. This map was made using openstreetmap. The two classes refer to the results of the latent class model presented in section 4.2.2.

\section{Methodology}

\subsection{Semi-structured interviews and focus group discussions}

Villages are administratively subdivided in quarters. To be systematic, one SSI was conducted with the quarter head of each quarter of the six villages in our sample. Interviews included the following topics: the historical and geographical background of the region, villagers' perceived landslide risks, their general attitudes towards resettlement, their previous experience with resettlement attempts and group dynamics regarding the decision to resettle. The interviews were conducted in English, but, when necessary, family members of the interviewee served as translators. Together with a SSI of the paramount chief and of the chief of the neighboring tribe, a total of 19 interviews were conducted of approximately $1 \mathrm{~h} 30$ each.

A FGD was performed in each village (two FGDs were conducted in the larger village of Nkongle, making a total of seven FGD), consisting of 6 people on average, who were randomly drawn from a list of household heads. Gender was not balanced, but it is in proportion with the relative number of female household heads (13\%). A facilitator was present for translation and clarification purpose.

The combination of SSIs and FGDs allowed to nuance and cross-check the statements made by the village heads, confront the official narrative with internal struggles in the village and learn additional insights from personal experiences. We also checked the validity of the statements with reports in official documents. These documents include administrative maps, the whitepaper on spatial planning made by the Support Programme for the Structuration of Civil Society in Cameroon and written communication between the village heads, the paramount chief and the ministry of territorial administration.

\subsection{Structured household survey and choice experiment}

During the period of August-October 2017, 350 household heads were surveyed from the six villages at the edge of the caldera. Based on our fieldwork, these villages are expected cover the majority of the inhabitants in the landslide-prone areas of the caldera. The household heads were randomly selected from lists created by the village heads of the respective villages or from existing microcredit lists. The number of respondents in each subsample was proportional to the number of households in each village. 
The survey consisted of a face-to-face interview with the household head. Interviews lasted for approximately 45 minutes per farmer and were carried out very early in the day to limit interference with the farmers' activities. The interview included questions on socio-demographics and a Discrete Choice Experiment. A DCE is a quantitative technique for eliciting individual stated preferences (Mangham et al., 2009; Nguyen et al., 2015). It allows to uncover how individuals value selected properties of a product, service or program by asking them to choose between hypothetical alternatives. These alternatives possess several features, called attributes. By eliciting choices, values are inferred for the different attributes and their levels. The method is based on random utility theory, which assumes that (i) every alternative comes with a certain amount of utility for the respondent, (ii) the utility of an alternative depends on its attribute level and (iii) the probability of an alternative to be chosen depends on the relative utility it provides compared to the other alternatives (rational utility maximization principle) (de Bekker-Grob et al., 2012; Mangham et al., 2009; WHO, 2012). Because of these assumed properties, a DCE can be used to derive the amount of utility that attribute levels bring to the respondent and the extent to which respondents are willing to trade between attributes (Mangham et al., 2009). Based on these choices, preferences are estimated using the maximum likelihood estimates in logit models.

\subsubsection{Attributes and attribute levels}

A list of attributes was made, containing the most important controlling factors for the success of a hypothetical resettlement program (Table 2). This list was based on the literature (Mberu et al., 2013; Vlaeminck et al., 2016), expert opinion and field visits (including some of the SSI and FGD). The attribute levels were determined based on the feedback received from the enumerators and respondents during a test-run. The attribute travel distance is the one-way time required to walk from the old settlement to the new settlement. This was considered a proxy for cultural, economic and social consequences of moving, which has been found to influence willingness to resettle (Vlaeminck et al., 2016). We used 3 levels ranging from half an hour to 4 hours of walking. Family action portrayed the resettlement action taken by the neighboring friends and extended family (defined as close or distant blood relatives - note that the household members were always supposed to move together), reflecting the consequences resettlement may have for social networks. There were three different levels for this attribute: one where the extended family moved along with the respondent, one where the extended family moved to a separate location from where the respondent was moving, and one level where the extended family and friends stayed in the original settlement while the respondent did resettle. Some of the proposed resettlement programs included extra arable land at the resettlement location, ranging from only a minor plot for the house, to 2 plots of $50 \mathrm{~m} \times 50 \mathrm{~m}$ for farming. An important presumption is made that farmers can retain their old farming plots on top of the newly received plots, although they might be less accessible due to the increased walking distance. This way, they can still access the fertile, humid soils inside the caldera during the dry season, while they can stay away in periods of heavy rainfall. This assumption is realistic, since there are already some farmers who only come to the caldera in the dry season, when soils are wet relatively to other soils outside the caldera, when the chance of landslides is low and when food prices are high. Also, the newly received plots are presumed to be situated near the resettlement area, which is a non-explicit location just outside of the caldera. Fertility of these newly received plots was understood by the respondents to be similar to the soil at the caldera edge, which is homogenously distributed in terms of fertility (Tematio et al., 2004).

The attribute for "absense of landslides" expresses whether there are life-threatening landslides at the resettlement location. This attribute was included into the choice experiment because we did not want to presume that a resettlement decision is only driven by fear of landslides. There might be other reasons why people want to resettle, such as improved road access. Consequently, the road infrastructure at the resettlement location was used as the fifth attribute. Three levels were included for this attribute, namely, 30 minutes of walking to the nearest road accessible by motorcycle, having an all year motorcycle road that can be passed by car in the dry season, and a road that is accessible for cars yearround. Lastly, a one-time financial compensation was included, ranging up to 4 million CFA franc. 
Table 2: Attributes and attribute levels. The attribute level perceived as least beneficial, was used as a reference category (RC) (indicated with 0). A higher preference is expected for the attribute levels with improved conditions.

\begin{tabular}{|c|c|c|}
\hline Attribute & Attribute levels & Explanation \\
\hline Travel distance & $\begin{array}{ll}0 . & \text { Four hours } \\
\text { 1. } & \text { Two hours } \\
\text { 2. } & \text { Half an hour }\end{array}$ & $\begin{array}{l}\text { Walking distance between } \\
\text { former house and } \\
\text { resettlement location. }\end{array}$ \\
\hline Family action & $\begin{array}{l}\text { 0. Does not resettle } \\
\text { 1. Resettles to other location (far from where you go) } \\
\text { 2. Resettles to the same location }\end{array}$ & $\begin{array}{l}\text { Decision of neighboring, } \\
\text { extended family and } \\
\text { friends to move. }\end{array}$ \\
\hline Extra arable land & $\begin{array}{l}\text { 0. Plot for house }+ \text { no extra plots } \\
\text { 1. Plot for house }+1 \text { plot for cultivation }(50 \times 50 \mathrm{~m}) \\
\text { 2. Plot for house }+2 \text { plots for cultivation }(50 \times 50 \mathrm{~m})\end{array}$ & $\begin{array}{l}\text { Area of land offered at } \\
\text { resettlement location. }\end{array}$ \\
\hline $\begin{array}{l}\text { Absence of } \\
\text { landslides }\end{array}$ & $\begin{array}{l}\text { 0. Landslides } \\
\text { 1. No landslides }\end{array}$ & $\begin{array}{l}\text { Presence of landslides at } \\
\text { resettlement location. }\end{array}$ \\
\hline Road infrastructure & $\begin{array}{l}\text { 0. Footpath: more than } 30 \text { minutes on foot to } \\
\text { motorcycle road } \\
\text { 1. All-year motorcycle road, but no car in rainy } \\
\text { season } \\
\text { 2. All-year Hilux road }\end{array}$ & $\begin{array}{l}\text { Road infrastructure at the } \\
\text { resettlement location. }\end{array}$ \\
\hline Compensation & $\begin{array}{ll}\text { 0. } & \text { None } \\
\text { 1. } & 100000 \text { CFA franc } \\
\text { 2. } & 500000 \text { CFA franc } \\
\text { 3. } & 1000000 \text { CFA franc } \\
\text { 4. } & 2000000 \text { CFA franc } \\
\text { 5. } & 4000000 \text { CFA franc }\end{array}$ & $\begin{array}{l}\text { Monetary compensation } \\
\text { offered to the household } \\
\text { for resettling ( } 655 \text { CFA } \\
\text { franc }=€ 1) \text {. }\end{array}$ \\
\hline
\end{tabular}

\subsubsection{Experimental design}

A D-efficient design of 24 choice cards divided over 3 blocks was made using the Ngene software. Every choice set consisted of 2 alternatives and an opt-out (Figure 3Figure 2). Including an opt-out does not force a choice on the respondent if they would not choose any of the two options in real life, which would lead to inaccurate estimates of welfare (Hanley et al., 2001; Hoyos, 2010).

The respondent received one block of 8 choice sets and therefore had to consider 24 alternatives $(8$ * (2 alternatives +1 opt-out)). By limiting the number of alternatives that the respondent has to consider, it is avoided that boredom sets in (Hanson et al., 2005; Mangham et al., 2009). Attribute overlap and correlation between blocks and enumerators were avoided. Due to a mistake during the coding of the D-efficient design for the choice cards, 13 out of 24 choice cards propose 2 alternatives which have the same monetary compensation. This could have impacted the analysis of the price-effect. No overlap took place for any of the other attribute levels. 


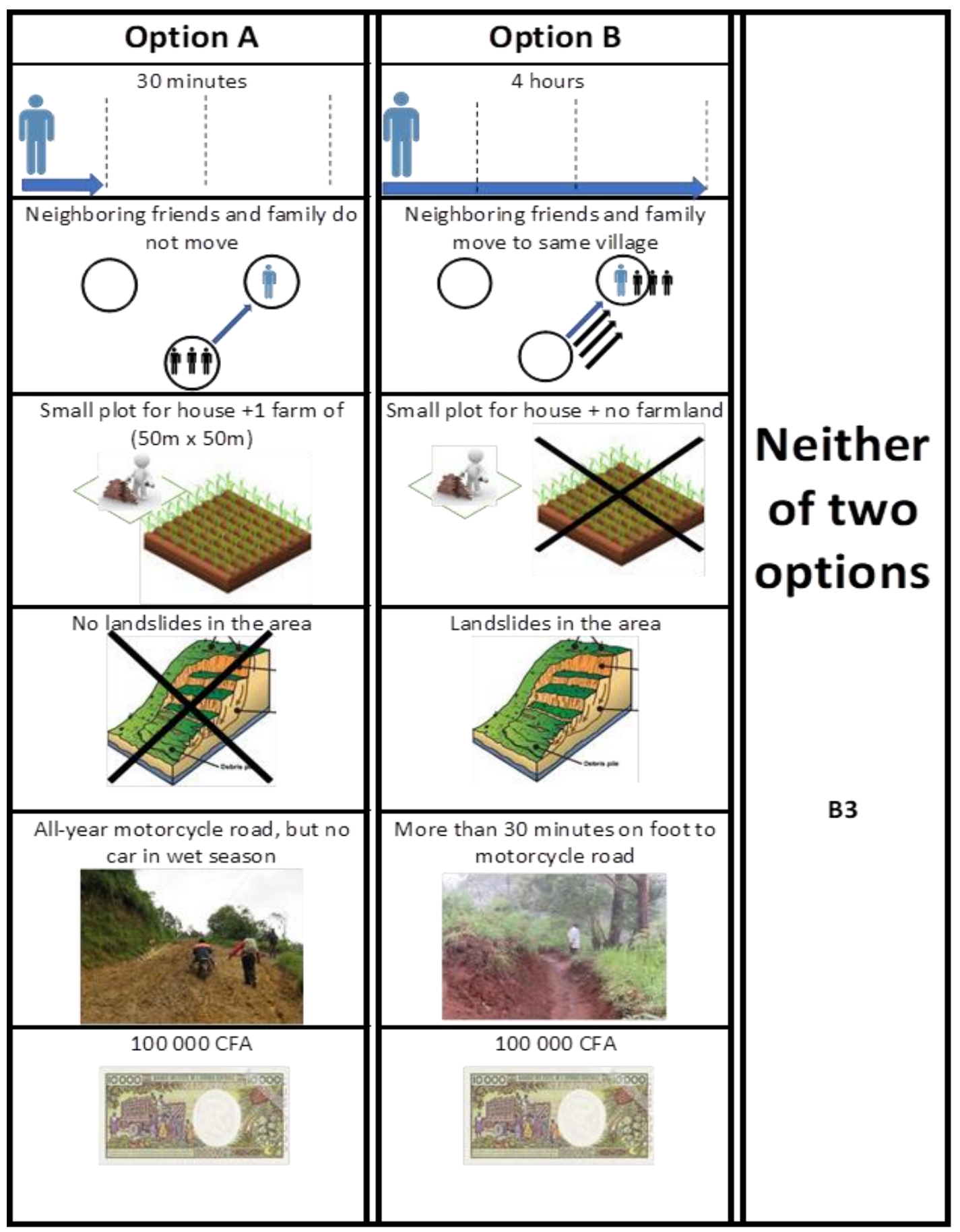

Figure 3: Example of a choice card used in the choice experiment.

\subsubsection{Questionnaire}

The questionnaire aimed at identifying the household composition, landslide experience and socioeconomic group. Agricultural income was roughly estimated based on self-reported crop yields, selling prices and non-agricultural income. Also, the number of plots and acreage was inquired for. After the DCE, respondents were asked to motivate their choices in the choice experiment. These motivations were used to cross-check the results and to test for attribute non-attendance. The location of every household was recorded using GPS coordinates. 


\subsection{Econometric models}

For the econometric analysis of the DCE, two logit models were used: the mixed logit model (MXL) and the latent class model (LCM). For the effect of the attribute levels, dummy coding was used, since it facilitates interpretation of preferences. Consequently, it is expected that for dummy coding, all coefficients are positive. The attribute of compensation is numerical and was not coded. For the interpretation of the alternative specific constant (ASC), separate effects-type coded regressions were performed. This is required, because in the dummy coded regression, the utility of the ASC cannot be separated from the utility associated with the attribute levels that are coded as the reference category (Bech and Gyrd-Hansen, 2005), leading to incorrect interpretation.

\subsubsection{Mixed logit model}

The MXL allows for heterogeneous taste variation, meaning that the model allows for different individuals to have differing resettlement preferences. It does this by estimating an average preference for every attribute and a standard deviation of how individuals' preferences vary around this population average (according to a distribution predefined by the researcher). A high standard deviation of a parameter's effect indicates high heterogeneity of the preference for the associated attribute level (Birol et al., 2006; Ryan et al., 2008).

The utility $U_{i j}$ for an individual $\mathrm{i}$ associated with scenario $\mathrm{j}$ is displayed as $U_{i j}=\left(\beta+\gamma_{i}\right) x_{i j}+\varepsilon_{i j}$, where $x_{i j}$ is the vector containing the observed characteristics of individual $i$ and the observed attribute levels of alternative $\mathrm{j}, \beta$ is the vector containing the coefficients associated with the utility effect for the different characteristics and attribute levels, $\gamma_{i}$ is the vector containing the personalized standard deviations of individual i from the mean effect $\beta$ and $\varepsilon_{i j}$ is the stochastic error term (Birol et al., 2006; Cascetta, 2009; Hoyos, 2010).

\subsubsection{Latent class model}

The LCM presumes that the population can be divided into a finite number of groups so that within groups, preferences of individuals are homogeneous, while between groups, preferences of individuals are heterogeneous. However, the variable that defines these groups is unknown (Magidson and Vermunt, 2002; Ryan et al., 2008). The LCM allows estimation of these groups, also called classes or segments. Individuals are assigned to the class with the highest membership probability based on their estimated preferences. Preferences are then estimated per class. After individuals are assigned to classes, the preferences of the classes can be linked to the socioeconomic characteristics that were registered in the household survey. This way, it is possible to get a view on what descriptive characteristics correlate with different classes and what the differences in preferences between these classes are (Ryan et al., 2008). The identification of these different classes can then be used to provide policies that are customized to these classes, leading to a higher utility for the individuals in the classes.

The utility $U_{i j l}$ for an individual i of class I associated with scenario j can be displayed as $U_{i j l}=\beta x_{i j l}+$ $\varepsilon_{i j l}$, where contains the characteristics, attribute levels and classes, $\beta$ is the vector containing the coefficients associated with the utility effect for the different characteristics and attribute levels for the differing classes and $\varepsilon_{i j l}$ is the stochastic error term.

Because the numerical values are confounded with a scale parameter, we cannot compare the classes directly. Solving this with the commonly used willingness to pay (WTP) estimates comes with a few problems. First, we find it unethical to put a price on resettlement because this could be used to benchmark what is 'sufficient' compensation for resettlement. Second, our estimate for monetary compensation is inconsistent, meaning WTA calculations would be unreliable. We circumvent this with the use of the relative attribute importance, which is obtained by: (i) calculating the utility range per attribute, (ii) adding up these ranges, (iii) divide the utility range of each attribute by the sum of all utility ranges (Lizin et al., 2012). A major disadvantage of working with relative attribute importance is that no statistical tests exist to effectively evaluate whether an attribute is more important than another across different classes. No strong recommendation should therefore be formulated from these results alone. 


\section{Results and discussion}

\subsection{Background of investigated villages}

Experiences with landslides and resettlement vary across the villages in the caldera. From the qualitative interviews it became clear that factors at village level impact resettlement preferences. Therefore, the past events in the sample villages are discussed in this section.

\subsubsection{Fomenji: no resettlement experience, isolated, low population pressure}

In Fomenji, clear signs of recent landslides, at less than 10 meters from property, were observed. When interviewed about this topic, the villagers explained that they were aware of the problem. However, the village head argued that his village would only resettle if the situation would further degrade, explaining that since there is still ample space available, individuals can be resettled to a plot nearby when needed. If that would no longer be possible, the village head would consider moving the village to the plains just outside the caldera. Although this attitude seems justified, subsequent villages will prove that this strategy comes with obstacles.

\subsubsection{Magha: unsuccessful resettlement attempt, accessible, medium population pressure}

According to current responses, no one in Magha was considering resettlement before 2003. Minor landslides had occurred before, but never had a landslide caused significant damage, let alone taken a life. That changed on the $20^{\text {th }}$ of July 2003 , when a major landslide occurred close to the center of Magha and 23 people perished beneath the rubble (Morikang, 2003; Sassa and Canuti, 2008). Additionally, the sloth caused flooding in lower-lying areas, which resulted in the destruction of 261 houses, 52 bridges, 86 culverts, 496 farms, 385 livestock killed, 229 families displaced and 1015 persons displaced (Sassa and Canuti, 2008). The disaster therefore sparked action from the community, which decided to move up to a flat area on the caldera ridge called "Setoh". A commission was sent by the government to visit the place of the disaster. During this visit, the resettlement location, which was covered in grasslands, was inspected and deemed appropriate. Additionally, the commission made the pledge to provide every affected household a sum of 400,000 CFA franc $(€ 600)$. Furthermore, the government promised to provide public infrastructure on the location of the new settlement. Following these events, houses were built, and the government constructed a medical center at Setoh.

However, Setoh is situated at the border between two tribes: the Magha people and the Pinyin people. Despite the land being mostly unused, the resettlement attempt of the Magha people was perceived as an encroachment on the land of the Pinyin. Hereafter, conflict ensued, and the Pinyin people chased the Magha settlers off the terrain. These actions were accompanied by violence: reports speak of destruction of property, physical beatings and minor bloodshed (Follah, 2006). No actions were taken by authorities to further enforce the resettlement plan (Ketu, 2015). The department of the organization of territory states that it is not actively dealing with the land dispute around Magha.

Currently, the Magha people are living on the same location as where the landslide struck them in 2003. They are still waiting for a sign of the government. Of the 400,000 CFA franc promised by the commission in 2003, the affected households saw 40,000 CFA franc. Allegedly, the remaining amount was lost due to venation. Nothing remains of the settlement of Setoh, not even the medical center. There is no active conflict between the two tribes, but the relations remain tense. A nobleman from the Pinyin described the situation as follows: "l eat with them with a long spoon."

\subsubsection{Atsualah: successful resettlement in 2003, accessible, medium population pressure}

After being minorly affected by the landslide event of July 2003, the village head of Atsualah advised villagers to resettle out of the caldera, next to the road. Based on the microcredit list, we estimate that approximately three out of four households in the village have resettled. However, before the resettlement, the land on top of the caldera ridge was already inhabited by a neighboring tribe, so that plots had to be purchased. The transfer of land from one tribe to another is a sensitive matter. Consequently, the price of the land was high: for a plot of one hectare, the price ranged from 0.5 to 1.5 million CFA franc $(€ 770$ to $€ 2,300)$. 
According to the group discussion, not everyone that resettled did so because of landslides. Some moved because they wanted to stay close to their communities (that had already resettled), whilst others argued that they liked being closer to the road. Likewise, not everyone moved at the same time: some individuals moved only eleven years after the landslide event. Specifically, two widows postponed resettlement due to financial constraints: "Those women needed more time to amass the means to come up, because they have to pay for it on their own." Due to liquidity constraints, most houses in upper (new) Atsualah are built out of wood instead of mud bricks

Those households that still have not moved argue either that they do not feel that the landslide threat outweighs the hassle of resettlement or that they could not finance a resettlement. The village head of the village has also not moved, stating he felt safe at his old location. However, the focus groups argued that he does not want to leave his palace, which is linked to his status.

Shortly after the start of the resettlement, the government came to Atsualah and gave a limited amount of financial support (20,000 CFA franc per household). According to the inhabitants, the government officials had promised that corrugated aluminum sheets for roofs and more financial support was to come. On August 2017, no such aid was provided.

\subsubsection{Aghong \& Marita: successful resettlement in 1988, accessible, medium population pressure}

The villages of Aghong and Marita moved in 1988, before the major landslides occurred, to have improved access to the road. At the time of their resettlement, the land at the resettlement destination was not claimed by any other chief. Therefore, no tribute had to be paid for acquiring the land. However, in 2004 a problem arose. The lands had originally been bought by a forestry company. When this company left the area unused, it returned under the control of the central government, where the ministry of forestry designated the land as a protected ecological zone. Consequently, since the villagers had encroached on a protected ecological zone, they received an eviction notice in March 2009. The village head of Aghong went to court and in 2011 an agreement between the parties was achieved (KFA, 2011). The villagers were allowed to stay. The management plan for the ecological zone was adapted and it now considers the developmental needs of the local population.

\subsubsection{Nkongle: no resettlement experience, accessible, high population pressure}

The respondents in Nkongle saw an increasing trend of people building on increasingly unstable land due to increasing population pressure: "There are no plots left, but the dangerous ones. [...] Our only alternative is to move to the city." Resettlement to a higher location is not possible, because the edge of the caldera is already inhabited. Resettlement deeper in the caldera, to areas with lower population density, is unpopular, because residents in the lower situated quarters speak Mundani, whereas the predominant language on top of this side of the caldera edge is M'mouck. Additionally, the village head stated that resettlement would mean that they would have to leave behind the "holy forest", associated with the culture and tradition of their tribe. This leaves the adolescents in these villages with little perspectives and possibilities. Either they build on an unsafe location, or they sell their assets and move to a major city.

\subsection{Willingness to move}

The average age of the household head in the sample is 42 years (Table 1, column 1). $87 \%$ of the household heads in our sample are male. About two thirds of the sample are of Mundani ethnicity and one third is M'mouck. The average degree of schooling in the sample is 6.98 years, which aligns with the standard schooling trajectory in Cameroon. 59\% of households stated to possess a motorized vehicle. On average, a household has an estimated 4.17 hectares of agricultural land and a total estimated yearly income of 3.11 million CFA franc (€4600).

\subsubsection{Mixed logit}

The results of the mixed logit model are shown in Table 3. Aside from the walking distance and "Family moves to other location" all the coefficients are positive and statistically significant. This confirms that 
the respondents show the same attribute level-preferences as hypothesized. This is important, because the design of the experiment is based on pre-defined assumed preferences for certain attribute levels. It also supports the idea that the respondents interpret the attribute levels in a similar fashion as we do, which is not self-evident, as local customs could have led to a difference of interpretation of the proposed attribute levels.

Respondents show a preference for resettlement programs where their neighboring family moves along. There is an inclination towards alternatives that provide additional farmland, the more the better, that offer financial compensation, that are free from landslides and have access to improved road infrastructure, especially paved roads. The effects-coded $\mathrm{MXL}^{1}$ has a statistically significant positive coefficient for "resettlement", indicating that there is a preference for resettling compared to staying in the original location irrespective of the attribute levels.

Aside from "Compensation" and the ASC, all parameters are treated as random parameters. The random parameters are assumed to be normally distributed. Preference heterogeneity was statistically significant on the 1\% level for all attributes but arable land. This shows that there is diversity in preferences within the sample. The result that the preference for receiving additional arable land is not heterogeneous indicates that land is of comparable value among different socioeconomic groups.

Table 3: Mixed logit model of the Wabane choice experiment. $N=345$ (5 excluded due to incomplete).

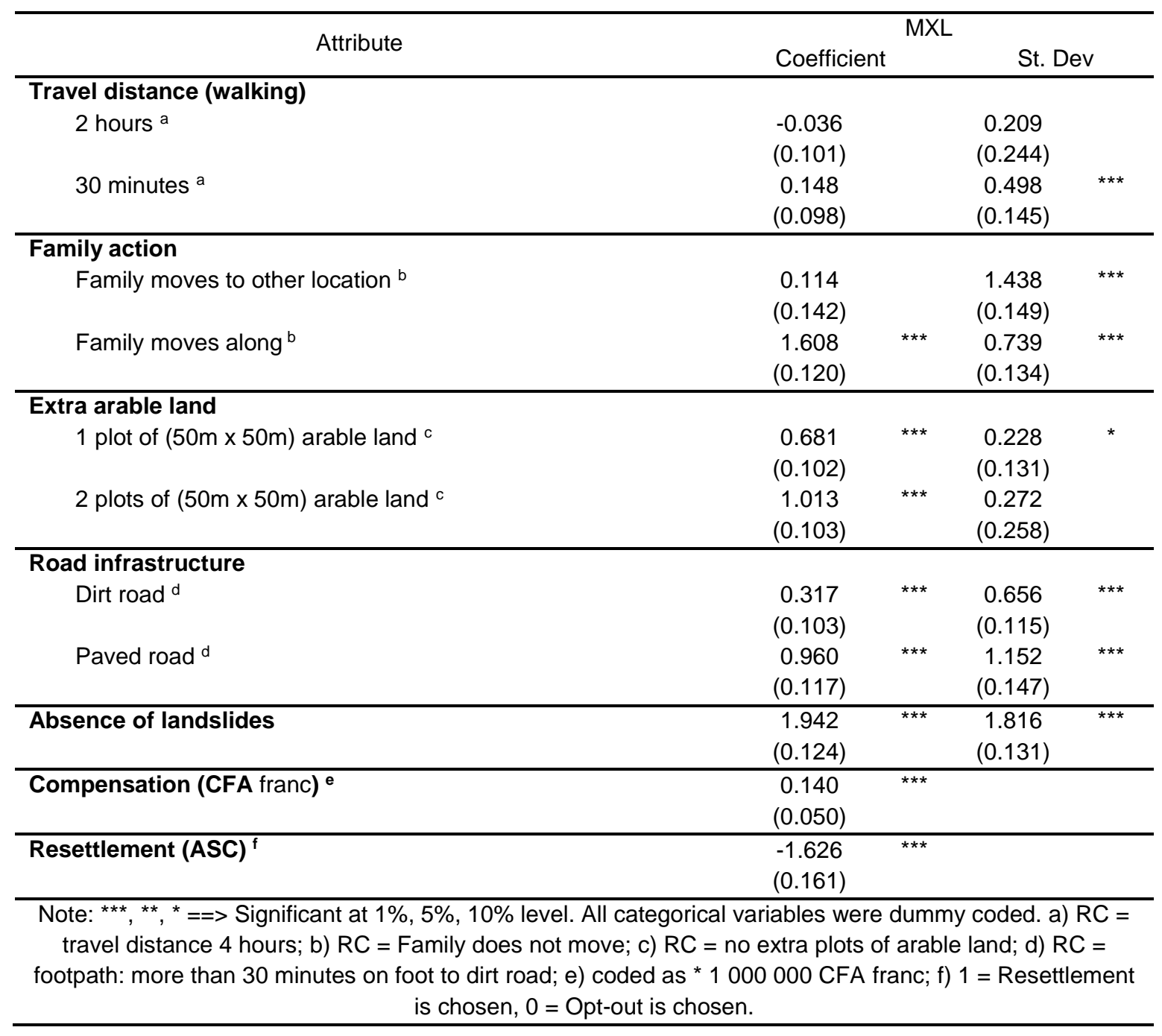

\footnotetext{
1 The effects-type coded mixed model resulted in an ASC with a coefficient of 0.530 , se (0.083), which was statistically significant at the $1 \%$ level.
} 


\subsubsection{Latent class Model}

The LCM is used to identify the socioeconomic groups with different preferences. The optimal number of classes was determined by using the NLOGIT software. The variance matrix fails to converge for three classes, meaning that the results for all higher numbers of classes are unreliable (Greene, 2018). Therefore, two latent classes are used for the analysis. Approximately $71.2 \%$ of the observations fall into class one and $28.8 \%$ in class two.

The estimates of the LCM are shown in Table 4. The parameter estimates show differences between the two classes on three aspects. Firstly, the positive coefficient for resettlement for class 1 indicates that the respondents in class 1 show a preference to resettle. Conversely, the negative coefficient for resettlement for class 2 indicates members of class 2 prefer not to resettle. This trend remains in the effects-type coded $\mathrm{LCM}^{2}$. Secondly, individuals in class 2 do not value the possibility where their family and friends can relocate to another village, whereas class 1 shows a significant preference for this attribute level over the reference category where the family does not relocate at all. Thirdly, class 1 shows a clearer preference for improved road infrastructure compared to class 2 . The attribute levels of travel distance but also of monetary compensation were insignificant.

Travel distance is not significant in any of the produced models. It appears less important in the light of a resettlement decision when compared against the other attributes. At first sight, this might seem to contradict the literature, which finds that the culture at the resettlement location (which is proxied by the attribute "travel distance") is one of the most important factors that people consider, since people might associate travel distance with cultural distance (Vlaeminck et al., 2016). However, it is also possible that the range of travel distances was insufficiently large to evoke a change in behavior. 4 hours of walking is long but not uncommon in these areas and might not be associated with impracticalities or large cultural differences.

While the offered amount of compensation is rather high (up to 4 million CFA franc, equivalent to more than the yearly average household income of the sample), we do not find a significant effect of compensation in the LCM (Table 4). This could mean that there is no strong preference towards compensation, but this interpretation is contradicted by the results of the MXL, which does identify a significant effect (Table 3). Three explanations are considered for the insignificance of the parameter in the LCM. First, the compensation levels might be interpreted differently by different respondents. Corruption is widespread in Cameroon. According to the qualitative interviews, households in Magha, for example, received only $10 \%$ of the promised sum of 400000 CFA franc during previous resettlement attempt. Because of this bad experience with the government, some villagers might have developed a distrust in promises of financial compensation and consider them vain, or they might consider the potential embezzlement and calculate an adapted, expected compensation. This expected compensation is then a fraction of the proposed compensation. If some respondents take this expected compensation into account when stating preferences, then for them the choice experiment has measured responses to "promised" levels of compensation rather than actual levels of compensation. The MXL is more robust to heterogeneous interpretations of the price offer than the latent class estimation and therefore still identifies a price effect. Secondly, the lack of trust in promised compensation might have lead respondents to ignore the attribute, leading to a bias related to attribute non-attendance. This is also suggested by the limited importance that is given to the attribute 'compensation' (Table 6). Third, the lack of variation in the monetary compensation which is present in part of the choice cards due to a mistake during their design might reduce variation in our sample to such an extent that the LCM does not capture the preference for compensation anymore.

\footnotetext{
2 The effects-type coded latent class model resulted in an ASC with a coefficient of 3.139 , se $(0.271)$, for class 1 and -0.9461 , se (0142), for class 2; both significant at the $1 \%$ level.
} 
Table 4: Latent class model of the Wabane choice experiment. $N=344$ (5 excluded due to incomplete, 1 dropped by NLOGIT).

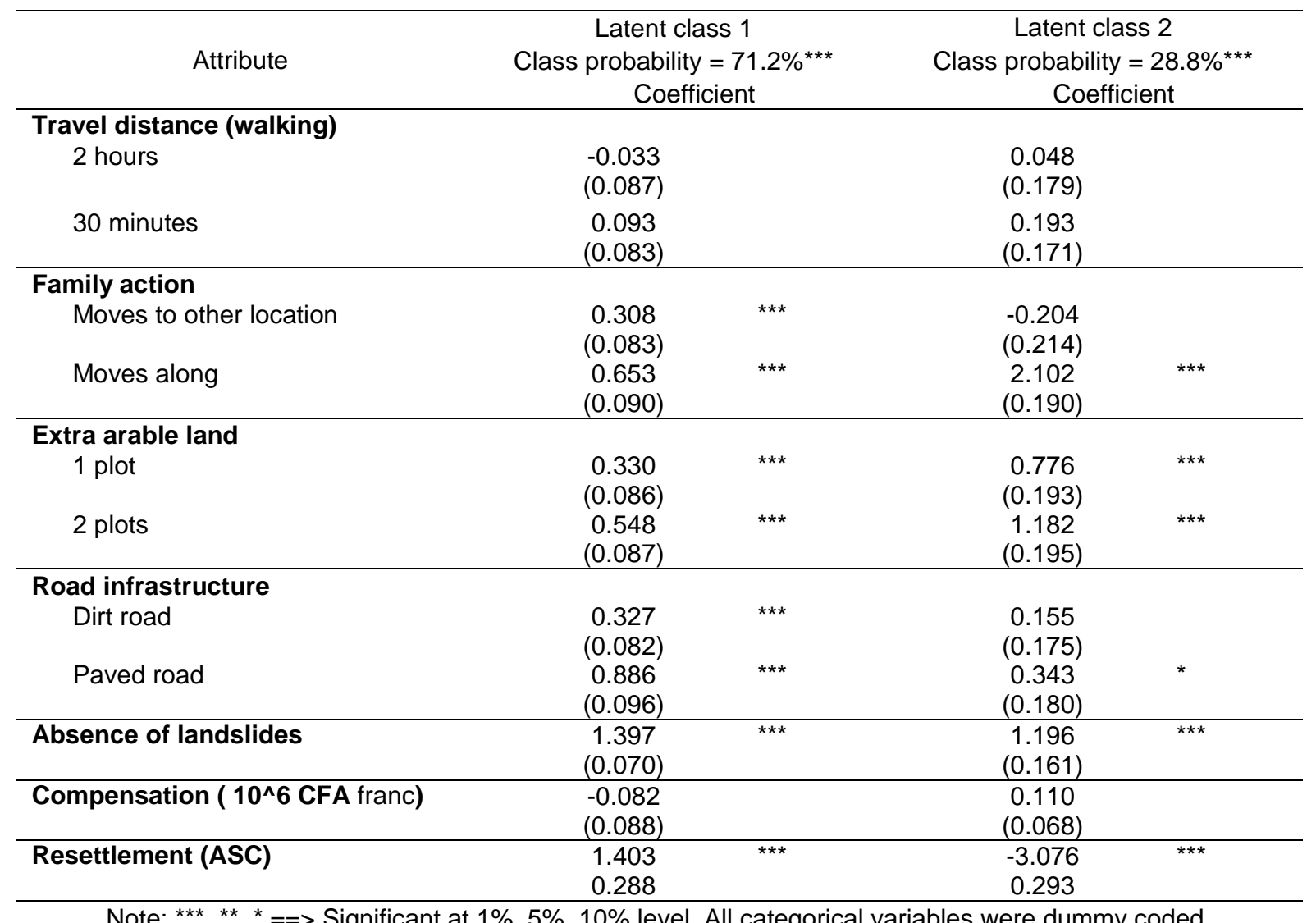

The relative importance of each attribute to the overall utility of the respondent is presented in Table 5. The general model indicates that respondents attach most importance to the absence of landslides and the resettlement actions of their extended family. Additionally, attention is given to the amount of land received and the road infrastructure at the resettlement location. Monetary compensation and travel distance are relatively unimportant. These observations are confirmed by what respondents identified themselves as being the most important attribute in the DCE (Table 6), showing that the respondents participated actively in the choice experiment.

Table 5: Relative attribute importance for the mixed model and for the two separate classes of the LCM. The full range for monetary compensation is obtained by multiplying the coefficient (which is shown for 1 million franc CFA) by four, so that the full attribute range is considered.

\begin{tabular}{lccc}
\hline & Mixed model & Latent class 1 & Latent class 2 \\
& $\mathrm{n}=344$ & $\mathrm{n}=245$ & $\mathrm{n}=99$ \\
\hline Travel distance & $2 \%$ & $2 \%$ & $2 \%$ \\
Family action & $20 \%$ & $12 \%$ & $26 \%$ \\
Arable land & $13 \%$ & $10 \%$ & $14 \%$ \\
Road infrastructure & $12 \%$ & $17 \%$ & $4 \%$ \\
Absence of landslides & $25 \%$ & $26 \%$ & $14 \%$ \\
Monetary compensation & $7 \%$ & $6 \%$ & $5 \%$ \\
Resettlement (ASC) & $21 \%$ & $26 \%$ & $35 \%$ \\
\hline
\end{tabular}


When the results of Table 5 and Table 6 are considered for the two separate classes, there is a clear distinction in preferences. Members of class 1 show a greater preference for the absence of landslides and improved road infrastructure at the resettlement location, while members of class 2 have their focus on the actions of their family and monetary compensation to a lesser extent (Table 6). Regarding the geographical distribution of the two classes, it seems that class 1 is overrepresented in the villages of Aghong, Atsualah and Marita (bottom right Figure 2, statistically significant at the $1 \%$ level), whilst it is underrepresented in Fomenji (top right in Figure 2, significant at the 1\% level).

When comparing the household characteristics of the two classes (Table 6), the results show that members of class 1 generally have more arable land, a higher income (both agricultural income and non-agricultural) and are more likely to possess a motorcycle (Table 6). This could be linked to their higher preference for paved roads: respondents who possess a motorcycle might have more benefits from paved roads or might be more familiar with the benefits that these roads can bring (e.g. market access). This knowledge of the benefits of road access might also be caused by the proximity of the road in the original settlement, which is also higher for class 1 (Figure 2).

Half of respondents in class 1 state that they have lost the life of a family member or a part of their house due to landslides. In class 2 , this is only $14 \%$ of respondents. Similarly, respondents in class 1 are more likely to have known someone who died in a landslide than respondents in class 2 (88\% vs $56 \%$ ) and are more likely to have moved the location of their house in the past due to a landslide. This can explain why the former attribute greater importance to resettlement locations that are safe from landslides and why they are more willing to resettle (Table 4Table 5). This observation seems to contradict earlier research, where wealthier individuals were found to be less affected by landslides (Vlaeminck et al., 2016). However, we believe that this is caused by a spatial effect. Members of class 2 , who have a lower monetary income, tend to live in more remote areas. These areas are isolated from markets, have a low population density and there is ample choice for housing away from landslides. As such their willingness to resettle is lower.

Alternatively, it is argued that poorer households are more risk averse (Dercon, 2002). Considering that a resettlement attempt is a costly and risky undertaking, it can be hypothesized that the poorer households consider the resettlement risk higher than the landslide risk. Conversely, wealthier households are more likely to take the risk of resettlement, because they have better mechanisms to cope with the downside risks of resettlement (Dercon, 2002).

The LCM illustrates that the respondents of class 1 prefer that their family is moved to safe location, irrespective of whether this is at the same location as themselves or not (Table 4). This was confirmed by the findings of the focus group discussions: "I cannot run away from the landslides and leave my family in this place." If this feeling prevails, then resettlement of the family to another location is still an acceptable alternative. Meanwhile, individuals of class 2 have a strong preference for a resettlement when their neighboring family can move along with them to the new location. Since these households are poorer, they probably rely more on their family network as a safety net. The relocation of your family to a separate location can disconnect you from your social network and restrain you from having access to the support associated with this network (Barcus and Werner, 2017; Morse and Mudgett, 2018; Mulder and Malmberg, 2014). 
Table 6: Average household characteristics for the full sample and for the separate classes.

\begin{tabular}{|c|c|c|c|c|}
\hline Characteristics & $\begin{array}{c}\text { Full } \\
\text { sample } \\
\text { Mean }\end{array}$ & $\begin{array}{l}\text { Latent } \\
\text { class } 1 \\
\text { Mean }\end{array}$ & $\begin{array}{c}\text { Latent } \\
\text { class } 2 \\
\text { Mean }\end{array}$ & $\begin{array}{c}\text { Significance } \\
\text { difference between } \\
\text { two classes }\end{array}$ \\
\hline \multicolumn{5}{|l|}{ General characteristics } \\
\hline Age of the $\mathrm{HH}$ head & 42.04 & 41.66 & 43.05 & \\
\hline$\%$ male $\mathrm{HH}$ head & $87 \%$ & $89 \%$ & $80 \%$ & ** \\
\hline Mundani ethnicity & $65 \%$ & $64 \%$ & $68 \%$ & \\
\hline M'mouck ethnicity & $35 \%$ & $36 \%$ & $32 \%$ & \\
\hline Years of education & 6.98 & 7.01 & 6.9 & \\
\hline Household members & 9.55 & 9.27 & 10.28 & \\
\hline Number of children (under 14) & 4.48 & 4.37 & 4.77 & \\
\hline $\mathrm{HH}$ born in current village & $79 \%$ & $80 \%$ & $78 \%$ & \\
\hline Foreign observer present ${ }^{\mathrm{a}}$ & $18 \%$ & $20 \%$ & $14 \%$ & * \\
\hline \multicolumn{5}{|l|}{ Welfare characteristics } \\
\hline Possession motorcycle & $59 \%$ & $66 \%$ & $43 \%$ & $* \star *$ \\
\hline Acreage (ha) & 4.17 & 4.84 & 2.42 & $* * *$ \\
\hline Total agric income (per year, $10^{\wedge} 6$ CFA franc) & 2.75 & 2.99 & 2.15 & ** \\
\hline Total non-agric income (per year, $10^{\wedge} 6$ CFA franc) & 0.35 & 0.48 & 0.04 & *** \\
\hline Total income (per year, $10^{\wedge} 6$ CFA franc) & 3.11 & 3.46 & 2.18 & *** \\
\hline \multicolumn{5}{|l|}{ Landslide related characteristics } \\
\hline $\mathrm{HH}$ ever lost life or house due to LS & $40 \%$ & $50 \%$ & $14 \%$ & *** \\
\hline HH knew someone who died due to LS & $79 \%$ & $88 \%$ & $56 \%$ & $* \star \star$ \\
\hline Moved because of LS & $17 \%$ & $19 \%$ & $9 \%$ & ** \\
\hline \multicolumn{5}{|l|}{ Most important attributes in CE (stated) } \\
\hline Distance to former plot & $1.4 \%$ & $1.6 \%$ & $1 \%$ & \\
\hline Family & $45 \%$ & $30 \%$ & $82 \%$ & *** \\
\hline Area of land & $28 \%$ & $28 \%$ & $28 \%$ & \\
\hline Road quality & $27 \%$ & $30 \%$ & $18 \%$ & *** \\
\hline Absence of landslides & $52 \%$ & $61 \%$ & $30 \%$ & $* \star *$ \\
\hline \multirow[t]{2}{*}{ Compensation } & $3.5 \%$ & $2.4 \%$ & $6.3 \%$ & ** \\
\hline & \multicolumn{4}{|c|}{ Note: ${ }^{* * *},{ }^{* *},{ }^{*}==>$ Significant at $1 \%, 5 \%, 10 \%$ level. } \\
\hline
\end{tabular}

\subsection{Reasons to stay}

The econometric analysis highlights that a large part of the population is willing to resettle to a location without landslides. However, such undertakings remain rare. This section considers these differences between actual behavior and stated preferences by investigating some of the underlying causes of why the individual willingness does not always translate into actions in the Bamboutos caldera.

\subsubsection{Group choices vs individual choices}

If the risk of landslides does not outweigh the risks of losing your social capital, the decision to resettle goes from a decision at the household level to a decision at the village level. Our results suggest that this might indeed be an important factor in the Bamboutos caldera. First, high preferences are found for resettlement programs that allow neighboring friends and extended family to move along to the new location, indicating that preserving family ties is considered essential. Second, the resettlement attempts in Atsualah and Magha were the result of group dynamics and a decision of an entire group of households to resettle. Third, in Fomenji individual respondents mention that they realize the gravity of the situation and admit that they are individually willing to resettle, but since individuals in their surroundings do not move, individual farmers do not feel the pressure to react themselves. This effect 
is named group inhibition or bystander effect (Latane and Darley, 1968). As long as there is no consensus within the community to resettle, the status quo remains. Consequently, a substantial proportion of the population might be willing to move, yet the group behavior supports the status quo.

\subsubsection{Obstacles to resettlement}

Even when the group choice is to resettle, five types of obstacles were encountered during the SSI's. (i) If population pressure becomes high, finding a suitable location for resettlement becomes difficult, as encountered around Nkongle, where smaller villages are willing to resettle, but there are no good alternative locations. (ii) If it is unclear where the boundary lies between communities, resettlement can lead to border disputes, as seen in the dramatic events that took place at Setoh. (iii) If resettlement is not officially registered, conflict might ensue with governmental planners, such as in Aghong, where villagers were nearly displaced after they had resettled into a protected ecological area. (iv) It might be difficult to leave behind the old location when there is a strong cultural link, as demonstrated by the village head of Atsualah, who advised others to resettle but did not do so himself. Similarly, the village head in Nkongle reported that he would not resettle because of the presence of a holy forest on the old location. (v) Resettlement is very costly, especially if land and building materials must be bought. While villagers in Atsualah successfully resettled, 14 years after the start of the resettlement many of them are still living in wooden houses of poor quality.

\subsection{An integrated approach to evaluate (future) resettlement programs}

This study illustrates the value of combining a DCE with FGD and SSI. DCEs allow detailed assessments of individual preferences towards resettlement. Yet, this assessment can be biased due to attribute nonattendance, unaccounted scale heterogeneity and the hypothetical nature of the questions. Attribute non-attendance could be a problem for the internal validity of our results because of two attributes: "travel distance" and "monetary compensation". Very few respondents have indicated that these attributes are the most important for them (Table 6), potentially leading to non-attendance. Nonattendance by some of the respondents could explain the limited significance, and sometimes inconsistent results, regarding these attributes in the analyses.

The hypothetical and artificial nature of DCE is a problem for the external validity of the results. The hypothetical nature of the questions in a DCE does not account for the real challenges and burdens that frequently come with resettlement programs. Moreover, the DCE only measures individual willingness without accounting for the group dynamics and therefore not being able to capture real-life collective actions. While a DCE is a valuable method for investigating ex-ante resettlement preferences of individual households, it is therefore questionable whether DCE can be used to estimate willingness to resettle without the combination with other, more qualitative analyses. An integrated approach to evaluate resettlement as a coping strategy, combining a DCE for individual preferences with FGD and SSI for group dynamics and real-life challenges, is therefore recommended. It combines the representativeness of large-scale surveys with the in-depth understanding of qualitative interviews. 


\section{Conclusion and recommendations}

This study combines a discrete choice experiment to identify preferences for resettlement with focus group discussions and semi-structured interviews to identify real challenges to resettlement in landslide prone areas in the Mount Bamboutos caldera in Cameroon. It aims at understanding conditions for success and failure of resettlement by contrasting preferences and actual behavior.

We find that there is a general willingness to resettle. However, this willingness is not always translated into a resettlement attempt. We put forward that the importance of social and cultural ties transforms the resettlement decision into a group decision. Consequently, when no consensus can be found, an attempt is impeded and the status quo (of not resettling) remains.

The results show that resettlement preferences are heterogeneous between socioeconomic groups. Individuals in poorer, more isolated communities attribute the greatest importance to the preservation of their social network, whilst households in richer, more connected communities are more sensitive to the presence of improved road infrastructure. We also find differences for the importance of the absence of landslides at the resettlement location for the two groups. This can be explained by the differences in exposure (due to differing levels of population pressure) and differences in risk behavior (due to differences in coping capabilities). These results illustrate that individuals from different communities have different requirements for a resettlement program to be acceptable and this should be considered in voluntary resettlement program.

Our results also demonstrate some reasons for not resettling. The behavior of other households in the village and of family members is important for effective resettlement. Also trust, in the local leader, but also in the promises from the government, is important to avoid disappointment and discouragement. In order to achieve a durable solution, neighboring tribes should be involved in the resettlement process and compensated for losses in access to land, since when this is not the case, the reactions of discontent neighbors might negatively affect a resettlement attempt.

This research shows the importance of qualitative research for evaluating future resettlement programs. It sheds light on group dynamics and past events that are hard to capture with a DCE. As such it allows to better understand why individual preferences are not in line with their actions. Additionally, it helps to better understand the local context and take this context into account when selecting the attributes (and their levels) of the DCE. We therefore recommend other researchers to complement their use of DCEs with qualitative research in the evaluation of disaster risk reduction strategies.

\section{Acknowledgements}

This study would have been impossible without the support of many people and organisations. That is why we would like to express our gratitude towards the AfReSlide Project, BR/121/A2/AfReSlide, titled 'Landslides in Equatorial Africa: Identifying culturally, technically and economically feasible resilience strategies', funded by the Belgian Science Policy (BELSPO) and the VLIR-UOS for their financial support. Moreover, the authors wish to express their appreciation to Ketung Eric, Mantap Heline Awapad, Cecilia Folah, Tezeme Roland Tegomon for their daily endeavors in the field. We also want to express our gratitude towards Pa Follah and Njoyim Hope Singwe, for their hospitality and patience, and to the local communities for their cooperation. Lastly, we wish to express our concern with the political situation in Cameroon, and we hope that talks can lead to a durable peace between the parties. 


\section{Bibliography}

Anderson, M.G., Holcombe, E., Blake, J.R., Ghesquire, F., Holm-Nielsen, N., Fisseha, T., 2011. Reducing landslide risk in communities: Evidence from the Eastern Caribbean. Appl. Geogr. 31, 590-599. https://doi.org/10.1016/j.apgeog.2010.11.001

Arnall, A., Thomas, D.S.G., Twyman, C., Liverman, D., 2013. Flooding, resettlement, and change in livelihoods: evidence from rural Mozambique. Disasters 37, 468-488. https://doi.org/10.1111/disa.12003

Artur, L., Hilhorst, D., 2014. Floods, resettlement and land access and use in the lower Zambezi, Mozambique. Land Use Policy 36, 361-368. https://doi.org/10.1016/j.landusepol.2013.08.017

Barcus, H., Werner, C., 2017. Choosing to Stay: (Im)Mobility Decisions Amongst Mongolia's Ethnic Kazakhs. Globalizations 14, 32-50. https://doi.org/10.1080/14747731.2016.1161038

Bech, M., Gyrd-Hansen, D., 2005. Effects coding in discrete choice experiments. Health Econ. 14, 1079-1083. https://doi.org/10.1002/hec.984

Birol, E., Karousakis, K., Koundouri, P., 2006. Using a choice experiment to account for preference heterogeneity in wetland attributes: The case of Cheimaditida wetland in Greece. Ecol. Econ. 60, 145-156. https://doi.org/10.1016/j.ecolecon.2006.06.002

Cascetta, E., 2009. Random Utility Theory, in: Transportation Systems Analysis, Springer Optimization and Its Applications. Springer, Boston, MA, pp. 89-167. https://doi.org/10.1007/978-0-38775857-2 3

Cernea, M., 1997. The risks and reconstruction model for resettling displaced populations. World Dev. 25, 1569-1587. https://doi.org/10.1016/S0305-750X(97)00054-5

Churchill, R.R., Hutchinson, D.M., 1984. Flood hazard in Ratnapura, Sri Lanka: Individual attitudes vs collective action. Geoforum 15, 517-524. https://doi.org/10.1016/0016-7185(84)90022-8

Cifrodelli, M., Corradini, C., Morbidelli, R., Saltalippi, C., Flammini, A., 2015. The Influence of Climate Change on Heavy Rainfalls in Central Italy. Procedia Earth Planet. Sci., World Multidisciplinary Earth Sciences Symposium, WMESS 2015 15, 694-701. https://doi.org/10.1016/j.proeps.2015.08.097

Claessens, L., Knapen, A., Kitutu, M.G., Poesen, J., Deckers, J.A., 2007. Modelling landslide hazard, soil redistribution and sediment yield of landslides on the Ugandan footslopes of Mount Elgon. Geomorphology 90, 23-35. https://doi.org/10.1016/j.geomorph.2007.01.007

Claudianos, P., 2014. Out of Harm's Way; Preventive Resettlement of at Risk Informal Settlers in Highly Disaster Prone Areas. Procedia Econ. Finance, 4th International Conference on Building Resilience, Incorporating the 3rd Annual Conference of the ANDROID Disaster Resilience Network, 8th - 11th September 2014, Salford Quays, United Kingdom 18, 312-319. https://doi.org/10.1016/S2212-5671(14)00945-9

Correa, E., Ramirez, F., Sanahuja, H., 2011. Populations at risk of disaster : a resettlement guide (No. 65355). The World Bank.

Crozier, M.J., Glade, T., 2005. Landslide Hazard and Risk: Issues, Concepts and Approach, in: Glade, T., Anderson, Icolm, Crozier, M.J. (Eds.), Landslide Hazard and Risk. John Wiley \& Sons, Ltd, pp. 1-40. https://doi.org/10.1002/9780470012659.ch1

Dai, F.C., Chin-Fei, L., Ngai, Y.Y., 2002. Landslide risk assessment and management: An overview. Eng. Geol. 64, 65-87.

de Bekker-Grob, E.W., Ryan, M., Gerard, K., 2012. Discrete choice experiments in health economics: a review of the literature. Health Econ. 21, 145-172. https://doi.org/10.1002/hec.1697

Dercon, S., 2002. Income risk, coping strategies, and safety nets. World Bank Res. Obs. 17, 141-166.

Ferris, E., 2014. Planned relocations, disasters and climate change: consolidating good practies and preparing for the future. Background document., in: Disasters Climate Change and Displacement. Presented at the Sanremo consultation, UNHCR. Brookings. Georgetown univeristy., Sanremo, Italy, p. 16.

Follah, P., 2006. Request for government intervention in Magha-Pinyin border dispute.

Froude, M.J., Petley, D.N., 2018. Global fatal landslide occurrence from 2004 to 2016. Nat. Hazards Earth Syst. Sci. 18, 2161-2181. https://doi.org/10.5194/nhess-18-2161-2018

Fujikura, R., Nakayama, M., 2012. The long-term impacts of resettlement programmes resulting from dam construction projects in Indonesia, Japan, Laos, Sri Lanka and Turkey: a comparison of land-for-land and cash compensation schemes. Int. J. Water Resour. Dev. 29, 4-13.

Gariano, S.L., Guzzetti, F., 2016. Landslides in a changing climate. Earth-Sci. Rev. 162, 227-252. https://doi.org/10.1016/j.earscirev.2016.08.011

Gariano, S.L., Rianna, G., Petrucci, O., Guzzetti, F., 2017. Assessing future changes in the occurrence of rainfall-induced landslides at a regional scale. Sci. Total Environ. 596-597, 417-426. https://doi.org/10.1016/j.scitotenv.2017.03.103 
Gountie, D.M., Nono, A., Njonfang, E., Kamgang, P., Zangmo, T.G., Kagou, D.A., Nkouathio, D.G., 2011. Le volcanisme ignimbritique de la Ligne du Cameroun (Mounts Bambouto et Bamenda, Ouest-Cameroun): signification dans la genèse des caldeiras | Request PDF. Bull. L'Institut Sci. Rabat Sect. Sci. Terre 33, 1-15.

Greene, W., 2018. Number of classes when matrix fails to converge.

Guedjeo, C.S., Kagou, D.A., Ngapgue, F., Nkouathio, D.G., Zangmo, T.G., Gountie, D.M., Nono, A., 2013. Natural hazards along the Bamenda escarpment and its environs: The case of landslide, rock fall and flood risks (Cameroon volcanic line, North-West Region). Glob. Adv. Res. J. Geol. Min. Res. 2, 15-26.

Hanley, N., Mourato, S., Wright, R.E., 2001. Choice modelling approaches: A superior alternative for environmental valuation? J. Econ. Surv. 15, 435-462.

Hanson, K., McPake, B., Nakamba, P., Archard, L., 2005. Preferences for hospital quality in Zambia: results from a discrete choice experiment. Health Econ. 14, 687-701. https://doi.org/10.1002/hec.959

Hoyos, D., 2010. The state of the art of environmental valuation with discrete choice experiments. Ecol. Econ. 69, 1595-1603. https://doi.org/10.1016/j.ecolecon.2010.04.011

Huggel, C., Gruber, S., Korup, O., 2013. 13.17 Landslide Hazards and Climate Change in High Mountains, in: Shroder, J.F. (Ed.), Treatise on Geomorphology. Academic Press, San Diego, pp. 288-301. https://doi.org/10.1016/B978-0-12-374739-6.00367-5

Kervyn, M., Jacobs, L., Maes, J., Bih Che, V., de Hontheim, A., Dewitte, O., Isabirye, M., Sekajugo, J., Kabaseke, C., Poesen, J., Vranken, L., Mertens, K., 2015. Landslide resilience in Equatorial Africa: Moving beyond problem identification! Belg. Rev. Belge Géographie. https://doi.org/10.4000/belgeo.15944

Ketu, I., 2015. Request for effective use of the feasability studies realized since 2008 on the disenclavement of Magha-Bamumbu disaster zone in Wabane subdivision.

KFA, 2011. White paper for a simple ecological reserve in the Bamboutos Massifs. Combining the imperatives of the survival of the residents and that of their off-springs on one hand, and the imperatives of conservation and preservation of biodiversity on the other hand. Knowledge For All. Support Programme for the Structuration of Civil Society in Cameroon., Mbouda.

Kita, S.M., 2017. Urban vulnerability, disaster risk reduction and resettlement in Mzuzu city, Malawi. Int. J. Disaster Risk Reduct. 22, 158-166. https://doi.org/10.1016/j.jjdrr.2017.03.010

Knapen, A., Kitutu, M.G., Poesen, J., Breugelmans, W., Deckers, J., Muwanga, A., 2006. Landslides in a densely populated county at the footslopes of Mount Elgon (Uganda): Characteristics and causal factors. Geomorphology 73, 149-165. https://doi.org/10.1016/j.geomorph.2005.07.004

Komori, D., Rangsiwanichpong, P., Inoue, N., Ono, K., Watanabe, S., Kazama, S., 2018. Distributed probability of slope failure in Thailand under climate change. Clim. Risk Manag. https://doi.org/10.1016/j.crm.2018.03.002

Lambi, C.M., Ndenecho, E.N., 2010. Ecology and Natural Resource Development in the Western Highlands of Cameroon. Issues in Natural Resource Management: Issues in Natural Resource Management. African Books Collective.

Latane, B., Darley, J.M., 1968. Group inhibition of bystander intervention in emergencies. J. Pers. Soc. Psychol. 10, 215-221. http://dx.doi.org.kuleuven.ezproxy.kuleuven.be/10.1037/h0026570

Lizin, S., Van Passel, S., De Schepper, E., Vranken, L., 2012. The future of organic photovoltaic solar cells as a direct power source for consumer electronics. Sol. Energy Mater. Sol. Cells 103, 110. https://doi.org/10.1016/j.solmat.2012.04.001

Maes, J., Molombe, J.M., Mertens, K., Parra, C., Poesen, J., Che, V.B., Kervyn, M., 2018. Socio-political drivers and consequences of landslide and flood risk zonation: A case study of Limbe city, Cameroon. Environ. Plan. C Polit. Space 2399654418790767. https://doi.org/10.1177/2399654418790767

Magidson, J., Vermunt, J.K., 2002. A Nontechnical Introduction to Latent Class Models.

Mangham, L.J., Hanson, K., McPake, B., 2009. How to do (or not to do) ... Designing a discrete choice experiment for application in a low-income country. Health Policy Plan. 24, 151-158. https://doi.org/10.1093/heapol/czn047

Mberu, B.U., Ezeh, A.C., Chepngeno-Langat, G., Kimani, J., Oti, S., Beguy, D., 2013. Family Ties and Urban-Rural Linkages among Older Migrants in Nairobi Informal Settlements. Popul. Space Place 19, 275-293. https://doi.org/10.1002/psp.1711

Mertens, K., Jacobs, L., Kabaseke, C., Maertens, M., Poesen, J., Kervyn, M., Vranken, L., 2016. The direct impact of landslides on household income in tropical regions: A case study from the Rwenzori Mountains in Uganda. Sci. Total Environ. 1032-1043.

Morikang, I., 2003. 21 people perish in landslides in Wabane. Cameroon-Info Net. 
Morse, C.E., Mudgett, J., 2018. Happy to Be Home: Place-Based Attachments, Family Ties, and Mobility among Rural Stayers. Prof. Geogr. 70, 261-269. https://doi.org/10.1080/00330124.2017.1365309

Mugagga, F., Kakembo, V., Buyinza, M., 2012. Land use changes on the slopes of Mount Elgon and the implications for the occurrence of landslides. Catena 39-46.

Mulder, C.H., Malmberg, G., 2014. Local Ties and Family Migration. Environ. Plan. Econ. Space 46, 2195-2211. https://doi.org/10.1068/a130160p

Ngoufo, R., 1992. The Bamboutos Mountains: Environment and Rural Land Use in West Cameroon. Mt. Res. Dev. 12, 349-356. https://doi.org/10.2307/3673685

Nguyen, Thanh Cong, Robinson, J., Whitty, J.A., Kaneko, S., Nguyen, The Chinh, 2015. Attribute nonattendance in discrete choice experiments: A case study in a developing country. Econ. Anal. Policy 47, 22-33. https://doi.org/10.1016/j.eap.2015.06.002

Reder, A., Rianna, G., Mercogliano, P., Pagano, L., 2016. Assessing the Potential Effects of Climate Changes on Landslide Phenomena Affecting Pyroclastic Covers in Nocera Area (Southern Italy). Procedia Earth Planet. Sci., The Fourth Italian Workshop on Landslides 16, 166-176. https://doi.org/10.1016/j.proeps.2016.10.018

Rianna, G., Zollo, A., Tommasi, P., Paciucci, M., Comegna, L., Mercogliano, P., 2014. Evaluation of the Effects of Climate Changes on Landslide Activity of Orvieto Clayey Slope. Procedia Earth Planet. Sci., The Third Italian Workshop on Landslides: Hydrological Response of Slopes through Physical Experiments, Field Monitoring and Mathematical Modeling 9, 54-63. https://doi.org/10.1016/j.proeps.2014.06.017

Ryan, M., Gerard, K., Amaya-Amaya, M. (Eds.), 2008. Using Discrete Choice Experiments to Value Health and Health Care, The Economics of Non-Market Goods and Resources. Springer Netherlands.

Sassa, K., Canuti, P., 2008. Landslides - Disaster Risk Reduction. Springer Science \& Business Media.

Sridarran, P., Keraminiyage, K., Amaratunga, D., 2018. Enablers and barriers of adapting post-disaster resettlements. Procedia Eng., 7th International Conference on Building Resilience: Using scientific knowledge to inform policy and practice in disaster risk reduction 212, 125-132. https://doi.org/10.1016/j.proeng.2018.01.017

Tematio, P., Kengni, L., Bitom, D., Hodson, M.E., Fopoussi, J.C., Leumbe, O., Mpakam, H.G., Tsozué, D., 2004. Soils and their distribution on Bambouto volcanic mountain, West Cameroon highland, Central Africa | Request PDF. J. Afr. Earth Sci. 39, 447-457. https://doi.org/10.1016/j.jafrearsci.2004.07.020

Toh, F.A., Angwafo, T.E., Ndam, L.M., Antoine, M.Z., 2018. The Socio-Economic Impact of Land Use and Land Cover Change on the Inhabitants of Mount Bambouto Caldera of the Western Highlands of Cameroon. Adv. Remote Sens. 7, 25-45. https://doi.org/10.4236/ars.2018.71003

Van Eynde, E., Dondeyne, S., Isabirye, M., Deckers, J., Poesen, J., 2017. Impact of landslides on soil characteristics: Implications for estimating their age. CATENA 157, 173-179. https://doi.org/10.1016/j.catena.2017.05.003

Vlaeminck, P., Maertens, M., Isabirye, M., Vanderhoydonks, F., Poesen, J., Deckers, S., Vranken, L., 2016. Coping with landslide risk through preventive resettlement. Designing optimal strategies through choice experiments for the Mount Elgon region, Uganda. Land Use Policy 51, 301-311.

Wabane Council, 2012. Wabane Communal Development Plan. Programme National de Developpement Participatif.

WHO, 2012. WHO | How to Conduct a Discrete Choice Experiment for Health Workforce Recruitment and Retention in Remote and Rural Areas: A User Guide with Case Studies. World health organization, Geneva.

Wouatong, A.S.L., Medjo Eko, R., Nankam, M.A., Kamgang Kabeyene Beyala, V., Ekodeck, G.E., 2014. Mineralogy, Geochemistry and Geotechnical Characteristics of Magha Landslides in the Bambouto Caldera, West Cameroon. J. Civ. Eng. Sci. 3, 36-49.

Yong Chen, Yan Tan, Yong Luo, 2017. Post-disaster resettlement and livelihood vulnerability in rural China. Disaster Prev. Manag. Int. J. 26, 65-78. https://doi.org/10.1108/DPM-07-2016-0130

Zangmo, T.G., Nkouathio, D.G., Kagou Dongmo, A., Wandji, P., Gountie Dedzo, M., Tchoua, F.M., 2011. Mount Bambouto Caldera (Cameroon Volcanic Line): Formation, structure and environmental impact. YES Netw. 1. 